\title{
Does Diversification Affect Capital Structure and Profitability in Pakistan?
}

\author{
Dr. Muhammad Azeem Qureshi \\ Associate Professor, Oslo \& Akershus University College, Oslo, Norway \\ E-mail: Muhammad-Azeem.Qureshi@hioa.no \\ Waqas Akhtar \\ Student MS (Finance), Institute of Management Sciences \\ Bahauddin Zakariya University, Multan, Pakistan \\ E-mail: waqas.01@hotmail.com \\ Muhammad Imdadullah \\ Visiting Lecturer, Institute of Management Sciences \\ Bahauddin Zakariya University, Multan, Pakistan \\ E-mail: imdadasad@yahoo.com
}

Received: September 26, 2011

Accepted: November 27, $2011 \quad$ Published: April 1, 2012

doi:10.5539/ass.v8n4p30

URL: http://dx.doi.org/10.5539/ass.v8n4p30

\begin{abstract}
Diversification has become a common strategy of corporate risk management along with availing other potential benefits. The intent of this study is to identify and analyze the nature of relationship that exists between diversification and capital structure as well as profitability in Pakistan. For this purpose we use the 10 years' (2000-2009) data of all the companies of chemical and food sector listed at the Karachi Stock Exchange (KSE). We find that the diversified firms are more profitable. Using independent variables of firm size, growth and tangibility the results show that whenever significant, the relationship is associated with greater amount of debt held by the firms.
\end{abstract}

Keywords: Capital structure, Profitability, Diversification, Pakistan

\section{Introduction}

Diversification; whether it be a product, business, or regional; has become a common strategy of corporate risk management along with availing other potential benefits. Consequently, we observe a proliferation of research relating diversification to the various components of the firm. However, most of these have been in the developed economies' context and we find paucity of such a research in Pakistani context. We propose to fill this gap with this study to help understand the phenomenon in Pakistani context and facilitate comparison with the research done in other countries.

Capital structure and profitability are two very essential components that reflect the firm's sustainability potential in the long-run. A number of studies depict capital structure as a dependent variable which is affected by various independent variables, such as profitability, growth opportunities, debt and non-debt tax shield, firm size, tangibility, ownership concentration and many others (DeAngelo \& Masulis, 1980; Harris \& Raviv, 1991; Jensen \& Meckling, 1976; Myers, 1984; Qureshi, 2009; Sheikh \& Wang, 2011). Moreover, various researches conducted on the effect of diversification on capital structure and performance evolved different schools of thought leading to the emergence of theories such as Coinsurance Theory (CT), Transaction Cost Theory (TCT), and Agency Theory (AT). Some argue that diversified firms need to have greater debt to maximize firm value (Kaplan \& Weisbach, 1992), which finds its empirical support as well (Li \& Li, 1996). However, negating these findings others find out that there is no association between leverage and diversification and many of the benefits 
associated with diversification are not in fact achieved (Comment \& Jarrell, 1995). Considering the classification of diversification into related and unrelated, some observe that the firms having related diversification have lower debt ratio than specialized firms, whereas unrelated-diversified firms have higher debt level (La Rocca, La Rocca, Gerace, \& Smark, 2009). Some others suggest resolutions to the conflicts along with identifying limitations of the earlier conflicting theoretical and empirical studies by further differentiating the diversified firms.

In the Pakistani context we attempt to identify and analyze the relationship between diversification and capital structure as well as profitability. We classify the diversification variable further as product diversification and geographic diversification. We intend to shed light on whether the firms really benefit from diversification in a developing economy, and also provide a platform for future research of similar orientation. Moreover, we intend to see which of theories identified hold in this context. We limit this study to the firms to two sectors of Karachi Stock Exchange (KSE); Chemicals and Food; due to problems associated with the data availability.

Along with the introduction in this section we organize this study as follows: we present theoretical framework with the help of review of relevant literature in section 2, we describe methodology in section 3 and present analysis and results in section 4, and in section 5 we present our conclusions. We provide references at the end.

\section{Theoretical framework}

To ground this study, we use the three fundamental approaches; CT, TCT and AT; that discuss the relationship between diversification and capital structure.

The CT refers to reduction of operating and financial risk of the firm operating in businesses whose streams of rents are imperfectly correlated (Lewellen, 1971). Coinsurance effect relates to the firms engaged in unrelated diversification strategies (Bergh, 1997; E. H. Kim \& McConnell, 1977). Primarily diversification is expected to reduce the risk faced by the firm and its lenders making it more sustainable in unfavorable conditions. A reduced volatility of firm revenues and profits leads to increased debt capacity of the firm (E. H. Kim \& McConnell, 1977).

The TCT relates the type of firm's excess resources and the nature of diversification. The firms possessing excess of related specialized resource will tend to go more towards related diversification and those with excess of unrelated/unspecified resources will go towards unrelated diversification. The nature of its diversification trajectory will dictate its financial decisions including the capital structure. High assets' specificity increases credit risk, making credit costly and such firms generally go for equity financing (Kochhar, 1996).

Severance of ownership and management in the firm creates the principal-agent problem resulting in agency cost to reduce the organizational performance (Jensen and Meckling 1976). The AT advocates the role of debt taken by the firm and its consequent committed cash outflows to limit imprudent managerial decisions such as higher spending on non-productive expenses as well as value-decreasing investments (Jensen, 1986). Considering diversification as value decreasing (Berger \& Ofek, 1995), this theory advocates negative relationship between diversification and debt.

The construct diversification was initially considered as the degree of heterogeneity of output of firm from the point of view of the number of markets served by that output (Gort, 1962); and the strategic management perspective grounds diversification in terms of product and market diversification (Ansoff, 1958). Product diversification implies the range of products in which the company is operating (La Rocca, et al., 2009). In order to develop theoretical framework we will review a number of studies that have investigated the relationship of different types of diversification with capital structure, firm value and profitability.

\subsection{Product diversification}

Contrary to the commonly eulogized elicitation, researchers observe the product diversification to be negatively related to firm value where the loss generally decreases in case the diversification is in related industry (Berger \& Ofek, 1995). But recently a U-shaped curvilinear inverse relationship is documented between product diversification and profitability (K.H. Kang et al. 2010). Further, simultaneous occurrence of product and international diversification results in increase in leverage, but this relationship does not necessarily hold when considering international and product diversification separately (Chkir \& Cosset, 2001). Moreover, diversification across product lines is at best unrelated to leverage after controlling for geographic diversification, asset turnover and firm size; it may be negatively related to leverage in some instances (Singh et al., 2003).

\subsection{Related and unrelated diversification}

To resolve some of the conflicts and contradictory findings of the earlier studies which considered diversification as single indivisible variable that may yield biased results, the recent researches consider the diversification as related and unrelated. They observe lower leverage and preference for equity financing in the related diversified 
firms that are based on business synergies as compared to their specialized counterparts, and high leverage in unrelated diversified firms based on financial synergies (La Rocca, et al., 2009). Additionally, the firms diversifying through acquisitions are more likely to use public sources of financing while the firms accentuating internal development of new businesses depend primarily on private sources of financing (Kochhar \& Hitt, 1998).

It is generally observed that the nature and availability of the resources to the firm may define the nature of its diversification trajectory. The tacit locked-in position of the firm due to specialized assets is more likely to facilitate related diversification and the firms possessing high levels of specialized and inflexible intangible assets attempt to transfer these resources across related businesses. The operational synergies across businesses leading to related diversification; and financial synergies leading to unrelated diversification help increase firm value (Chatterjee \& Wernerfelt, 1991). Further, related diversification provides more opportunities to increase firm value than unrelated diversification (Hitt \& Ireland, 1986).

\subsection{International diversification}

It is argued that the multinational corporations (MNCs) are likely to have higher leverage as they have lesser default risk due to their operations diversified in multiple countries (Eiteman et. al., 1998). However, contrary to this theorized relationship empirical studies observe the MNCs and their subsidiaries use lesser debt as compared to their domestic counterparts but gradually the leverage of MNCs increases with the increase of their foreign involvement (Burgman, 1996; Chen, Cheng, He, \& Kim, 1997; Fatemi, 1988; Michel \& Shaked, 1986; Qureshi, 2009). Moreover, there is no significant relationship between international diversification and firm performance (G. Qian, J. Li 2002; D.M. Brock, T. Yaffe 2008). However, some observe a positive but complex relationship between diversification and performance (G. Qian in 2002). But others argue that diversification whether it is industrial or geographic results decrease in firm performance (Y.S. Kim, I. Mathur; 2008).

We present in Table 1 below the identified relevant variables of diversification, their proxies and probable relationship with leverage.

$<$ Insert Table 1 Here $>$

\subsection{Other variables affecting capital structure}

The literature (La Rocca, et al., 2009) suggests that there exists a likely interaction between diversification variables and other variables like non-debt tax shield, ownership concentration, tangibility, firm size, andgrowth opportunities to affect corporate profitability and capital structure. Following (La Rocca, et al., 2009) we consider profitability and capital structure as dependent variables, and diversification as well as non-debt tax shield, ownership concentration, tangibility, firm size, andgrowth opportunities as independent variables to identify and analyze their relationship.

\section{Methodology}

The relevant literature proposes different methods to classify the firms as diversified and specialized, as well as related and unrelated diversified. But in Pakistan owing to lack of SIC coding we classify the firms as diversified and specialized on the basis of their product portfolio; whether the firm produces a single or multiple products; and markets; whether the firm sells only in domestic markets or domestic as well as export market.

We consider the firms from food and chemical sectors in our sample, and collect the related data from various sources including online publications, KSE, and the State Bank of Pakistan for 10 years spanning from 2000 to 2009. A total number of 74 companies of Chemicals and Food sectors listed at KSE make up our sample. We consider product and geographic diversification as the two dimensions of diversification. However in the Pakistani context where most of the firms are related diversified, we classify them into just two categories of diversified and specialized. Table 2 depicts the variables included in this study and their respective proxies along with the reasoning.

$<$ Insert Table 2 Here $>$

We use the following functional form to model the relationship of capital structure with the diversification and profitability along with moderating variables.

$$
\text { Capital structure }=\mathrm{f}(\text { diversification }+ \text { profitability }+ \text { firm size }+ \text { tangibility }+ \text { growth })
$$

We apply regression to the organized data to find the respective relationships among the included variables. First, we apply the procedure to all companies of both sectors combined and then to each sector separately. 
Table 3 depicts the descriptive statistics which indicate that almost half of the firms in the sample are diversified with respect to product and the rest are not diversified. On the other hand $39 \%$ of the firms are geographic diversified measured as whether or not the firm has export sales along with local sales. The volatile markets and economic conditions facing Pakistan reflect volatility in growth statistics which is also observable in debt ratio.

$<$ Insert Table 3 Here $>$

\section{Analysis, results and their discussion}

Table 4 presents correlation among all variables included in the study. We observe a strong positive correlation between product diversification and return on assets as well as the debt ratio, while a strong negative correlation with the degree of tangibility. Further, there exists positive correlation of geographic diversification with firm size, growth and debt ratio and return on assets depict a strong negative correlation with tangibility.

$<$ Insert Table 4 Here $>$

\subsection{Capital structure}

Taking debt ratio, a proxy for capital structure, as the dependent variable and rest of the variables (Table 4) as independent for all the firms of the two sectors the regression results in $\mathrm{R}^{2}=0.327$ and a p-value of 0.00 showing a strong relationship of the independent variables with the debt ratio. Moreover, taking 5\% significance level Table 5 exhibits that product diversification has positive relationship with debt levels indicating that decrease in corporate risk due to product diversification leads to increased capacity to take debt related risk, and thus provides support to the CT. The negative relationship of return on assets with the debt levels validates the pecking order theory (POT) and this finding also supports the findings of earlier studies in Pakistani context (Qureshi, 2009; Sheikh \& Wang, 2011). Moreover, tangibility exhibits a significantly positive effect on the debt levels which depicts the collateral value of these assets but our finding negates an earlier study in Pakistani context (Sheikh \& Wang, 2011), this divergence may be because of our choice of sample which is limited to only two sectors while that study uses the entire manufacturing sector.

$<$ Insert Table 5 Here $>$

\subsection{Profitability}

Table 6 shows the regression results of profitability, return on asset as its proxy, as dependent variable and rest of the variables taken as independent. Taking $5 \%$ significant level this table suggests that product diversification has positive effect on profitability but geographic diversification does not show a significant effect on the profitability. Firm size positively affects profitability, perhaps because larger the firm size greater is its bargaining power in the market. Further, tangibility has negative effect on the profitability; inefficient use of fixed assets may be a plausible explanation of this finding. Moreover, debt ratio also shows a negative relation with profitability indicating that the profitable firms use their cash flows to pay off their debt.

$<$ Insert Table 6 Here $>$

After the overall analysis for the two sectors, we now present the analysis of each sector in the following paragraphs.

\subsection{Capital structure - Chemical sector}

Analyzing the relationship of the capital structure (Table 7) with different variables we find that geographic diversification has a strong positive effect on debt ratio. As explained above it seems that the firms in this sector consider the geographic diversification as risk reducing strategic move that creates room for debt related capacity to take risk. On the other hand, return on assets has a strong negative relationship with the capital structure which conforms to POT as well as earlier studies in Pakistani context. Collateral value of fixed assets, labeled as tangibility is positively related to the capital structure negating an earlier study (Sheikh \& Wang, 2011).

$<$ Insert Table 7 Here $>$

\subsection{Profitability - Chemical sector}

Table 8 depicts the regression results of profitability as dependent variable which suggest that product diversification has a positive effect on the profitability. But the tangibility has a significant negative impact on the profitability which clearly indicates that most productive assets of this sector are non-fixed assets such as patents, trademarks, etc. Moreover, growth also contributes positively to the profitability negating an earlier study in Pakistani context (Sheikh \& Wang, 2011).

$<$ Insert Table 8 Here $>$ 


\subsection{Capital structure - Food sector}

Table 9 presents the relationship of capital structure of the firms of food sector with firm size, ROA and tangibility that are the most effective variables to determine the debt ratio. Firm size has a strong negative effect on capital structure. The plausible explanation could be that larger firms command not only goodwill but also have lesser informational asymmetry in the market place and consequently are likely to have more confidence of the market participants resulting in better chances to issue equity. Profitability demonstrates a strong negative relationship with the debt ratio, a universally observed corporate regulation which provides internal equity financing as a first choice rather than issuing external equity or taking debt. We observe a strong positive effect of tangibility on debt ratio indicating the use of collateral value of fixed assets to raise debt financing.

$<$ Insert Table 9 Here $>$

4.6 Profitability - Food sector

We depict the regression results of food sector in Table 10 which demonstrates the relationship of independent variables with profitability as dependent variable. Product diversification and debt ratio emerge as the most effective contributors to determine profitability in this sector; the earlier having a positive impact whereas the latter having a negative impact.

$<$ Insert Table 10 Here $>$

\subsection{Analysis with respect to firm size}

Since we do not observe any deterministic relationship of firm size with capital structure and profitability, we divide the whole sample into three distinct categories with respect to size; large, medium and small firms; and apply regression on each group separately. In the following paragraphs we discuss these results.

\subsubsection{Capital structure of large firms}

Table 11 shows that three independent variables yield a significant effect on capital structure of large firms: geographic diversification has a positive relationship; profitability shows a negative relationship; and tangibility depicts a positive relationship with debt. These findings reinforce the argument given in previous sections that diversified firms having large amount of fixed assets hold greater capability to get debt at lower cost from the lending institutions; and profitable firms tend to use their cash flows to pay off debt.

$<$ Insert Table 11 Here>

\subsubsection{Capital structure of medium firms}

As far as middle sized firms are concerned, Table 12 shows that another variable growth has become prominent variable in affecting the capital structure of these firms which has a strong negative impact on debt of the companies. The growth firms generally do not want to share the advantage of growth with the lenders. Rather they issue common stocks to raise money and share the increased worth of the company with the shareholders. A consistently strong negative relationship of return on assets with the debt again conforms to POT.

$<$ Insert Table 12 Here $>$

\subsubsection{Capital structure of small firms}

Table 13 depicts that most of the independent variables show insignificant relationship with debt ratio of small firms. Only geographic diversification shows a strong positive impact on the debt ratio. The firms exporting their products have significantly higher debt than the ones doing business locally.

\section{$<$ Insert Table 13 Here $>$}

\subsubsection{Profitability of large firms}

Taking profitability as dependent variable and all the other variables as the independent variables, Table 14 shows that only product diversification and tangibility have a strong effect on the profitability of large firms. The earlier holds a strong positive relationship and the latter shows a strong negative effect. This result for product diversification coincides with the result obtained from the collective analysis of the data. Tangibility also shows the same relationship with the profitability.

$<$ Insert Table 14 Here $>$

\subsubsection{Profitability of medium firms}

Table 15 presents profitability of the medium sized firms. We find that debt ratio has a strong negative impact on the profitability of these firms the same relationship we observe in section 4.7.2. 
$<$ Insert Table 15 Here $>$

\subsubsection{Profitability of small firms}

We find a positive relationship of profitability of small firms and their product diversification which we present in Table 16.

\section{$<$ Insert Table 16 Here $>$}

\section{Conclusion}

From the above empirical analysis several important patterns emerge that we summarize below:

First, the coinsurance theory and the transaction cost theory are supported by the results as the firms having product and geographic diversification have greater amount of debt as compared to the non-diversified firms. Second, the pecking order theory is consistently validated in almost in all cases.

Tangibility positively affects the debt ratio. Considering the profitability, product diversification positively affected the profitability, the diversified firms earning more on average. Same was the effect of size of firm on the earnings, larger the size greater the average profitability. Similarly debt and tangibility have negative relationships with the profitability

Firm size; classified into three categories, small, medium and large; affects firms' capital structure as well profitability. Geographically diversified large firms having high tangibility have positive impact of their profitability and they use their lesser operational risk to secure higher debt in their capital structure. Moreover, the growing medium sized firms do not share the expected benefit of growth with their creditors and avoid debt as the strong negative relationship of growth with debt ratio depicts. Furthermore, product diversification helps small firms not only to improve their profitability but also helps them raise their debt capacity.

The diversified firms; producing and exporting multiple products; have a greater capacity to bear debt due to their stability in any adverse situation which may cripple whole of the firm if it is specialized. The firms which are geographically diversified are also more profitable may be because of better product leading to greater product acceptability in the different markets. The results show a universal negative relationship between profitability and debt.

Our results may be interpreted considering its limitations which include: i. We use a sample of only two sectors due to data availability problem but increasing the sample size may yield better insights regarding the topic under discussion; ii. We classified the firms based on their product and/or geographic (market) diversification but we emphasize the need of developing a criterion of diversification similar to SIC to better classify the companies systemically.

\section{References}

Ansoff, H. I. (1958). A model for diversification. Management Science, 4(4), 392-414. http://dx.doi.org/10.1287/mnsc.4.4.392

Berger, P. G. \& Ofek, E. (1995). Diversification's effect on firm value. Journal of Financial Economics, 37(1), 39-65. http://dx.doi.org/10.1016/0304-405X(94)00798-6

Bergh, D. D. (1997). Predicting divestiture of unrelated acquisitions: an integrative model of ex ante conditions. $\begin{array}{llll}\text { Strategic Management } & \text { Journal, } & 18(9), & 715-731 .\end{array}$ http://dx.doi.org/10.1002/(SICI)1097-0266(199710)18:9<715::AID-SMJ912>3.0.CO;2-6

Brock, D. M. \& Yaffe, T. (2008). International diversification and performance: The mediating role of implementation. International Business Review, 17(5), 600-615. http://dx.doi.org/10.1016/j.ibusrev.2008.07.003

Burgman, T. A. (1996). An Empirical Examination of Multinational Corporate Capital Structure. Journal of International Business Studies, 27(3). [Online] Available: http://www.jstor.org/stable/155438

Chatterjee, S. \& Wernerfelt, B. (1991). The link between resources and type of diversification: theory and evidence. Strategic Management Journal, 12(1), 33-48. http://dx.doi.org/10.1002/smj.4250120104

Chen, C. J. P., Cheng, C. S. A., He, J. \& Kim, J. (1997). An Investigation of the Relationship between International Activities and Capital Structure. Journal of International Business Studies, 28(3), 563-577. http://dx.doi.org/10.1057/palgrave.jibs.8490111

Chkir, I. E. \& Cosset, J. C. (2001). Diversification strategy and capital structure of multinational corporations. Journal of Multinational Financial Management, 11(1), 17-37. [Online] Available: http://www.sciencedirect.com/science/journal/1042444X/11/1 
Comment, R. \& Jarrell, G. A. (1995). Corporate focus and stock returns. Journal of Financial Economics, 37(1), 67-87. [Online] Available: http://www.sciencedirect.com/science/journal/0304405X/37/1

DeAngelo, H. \& Masulis, R. W. (1980). Leverage and dividend irrelevancy under corporate and personal taxation. Journal of Finance, 453-464. [Online] Available: http://www.afajof.org/journal/browse2.asp? $\mathrm{ref}=0022-1082 \&$ vid $=35 \&$ iid $=2 \&$ oc $=\& \mathrm{~s}=$

Fatemi, A. M. (1988). The effect of international diversification on corporate financing policy. Journal of Business Research, 16(1), 17-30. http://dx.doi.org/10.1016/0148-2963(88)90078

Gort, M. (1962). Diversification and integration in American industry. NBER Books. [Online] Available: http://www.nber.org/chapters/c1932.pdf

Habib, M. M. \& Victor, B. (1991). Strategy, structure, and performance of US manufacturing and service MNCs: A comparative analysis. Strategic Management Journal, 12(8), 589-606. http://dx.doi.org/10.1002/smj.4250120803

Harris, M. \& Raviv, A. (1991). The Theory of Capital Structure. Journal of Finance, 46(1), 297-355. [Online] Available: http://links.jstor.org/sici?sici=0022-1082\%28199103\%2946\%3A1\%3C297\%3ATTOCS\%3E2.0.CO\%3B2-L

Hitt, M. A. \& Ireland, R. D. (1986). Relationships among corporate level distinctive competencies, diversification strategy, corporate structure and performance. Journal of Management Studies, 23(4), 401-416. http://dx.doi.org/10.1111/j.1467-6486.1986.tb00425.x

Jensen, M. C. (1986). Agency costs of free cash flow, corporate finance, and takeovers. The American Economic Review, 76(2), 323-329. [Online] Available: http://www.jstor.org/stable/1818789

Jensen, M. C. \& Meckling, W. H. (1976). Theory of the firm: Managerial behavior, agency costs and ownership structure. Journal of financial economics, 3(4), 305-360. http://dx.doi.org/10.2139/ssrn.94043

Kang, K. H., Lee, S. \& Yang, H. (2010). The effects of product diversification on firm performance and complementarities between products: A study of US casinos. International Journal of Hospitality Management, 30(2), 409-421. http://dx.doi.org/10.1016/j.ijhm.2010.06.008

Kaplan, S. N. \& Weisbach, M. S. (1992). The success of acquisitions: Evidence from divestitures. Journal of Finance, 107-138. [Online] Available: http://www.afajof.org/journal/jstabstract.asp?ref=11195

Kim, E. H. \& McConnell, J. J. (1977). Corporate mergers and the co-insurance of corporate debt. Journal of Finance, 32(2), 349-365. [Online] Available: http://www.afajof.org/journal/jstabstract.asp?ref=9276

Kim, Y. S. \& Mathur, I. (2008). The impact of geographic diversification on firm performance. International Review of Financial Analysis, 17(4), 747-766. http://dx.doi.org/10.1016/j.irfa.2007.09.007

Kochhar, R. (1996). Explaining firm capital structure: the role of agency theory vs. transaction cost economics. $\begin{array}{llll}\text { Strategic Management } & \text { Journal, } & 17(9), & \text { 713-728. }\end{array}$ http://dx.doi.org/10.1002/(SICI)1097-0266(199611)17:9<713::AID-SMJ844>3.0.CO;2-9

Kochhar, R. \& Hitt, M. A. (1998). Linking corporate strategy to capital structure: Diversification strategy, type and source of financing. Strategic Management Journal, 19(6), 601-610. [Online] Available: http://www.jstor.org/stable/3094048

La Rocca, M., La Rocca, T., Gerace, D. \& Smark, C. (2009). Effect of diversification on capital structure. Accounting \& Finance, 49(4), 799-826. http://dx.doi.org/10.1111/j.1467-629X.2009.00304.x

Lewellen, W. G. (1971). A pure financial rationale for the conglomerate merger. Journal of Finance, 26(2), 521-537. [Online] Available: http://www.afajof.org/journal/jstabstract.asp?ref=8328

Li, D. D. \& Li, S. (1996). A theory of corporate scope and financial structure. Journal of Finance, 51(2), 691-709. [Online] Available: http://www.afajof.org/journal/jstabstract.asp?ref=11612

Lim, E. N. K., Das, S. S. \& Das, A. (2009). Diversification strategy, capital structure, and the Asian financial crisis (1997-1998): evidence from Singapore firms. Strategic Management Journal, 30(6), 577-594. http://dx.doi.org/10.1002/smj

Menéndez-Alonso, E. J. (2003). Does diversification strategy matter in explaining capital structure? Some evidence from Spain. Applied Financial Economics, 13(6), 427-430. http://dx.doi.org/10.1080/ 09603100210150930

Michel, A. \& Shaked, I. (1986). Multinational corporations vs. domestic corporations: financial performance and characteristics. Journal of International Business Studies, 17(3), 89-100. http://dx.doi.org/10.1057/palgrave.jibs. 8490435 
Myers, S. C. (1984). The Capital Structure Puzzle. Journal of Finance, 39(3), 575-592. [Online] Available: http://www.afajof.org/ journal/jstabstract.asp?ref $=10308$

Qian, G., Li, L., Li, J. \& Qian, Z. (2008). Regional diversification and firm performance. Journal of International Business Studies, 39(2), 197-214. http://dx.doi.org/10.1057/palgrave.jibs.8400346

Qureshi, M. A. (2009). Does pecking order theory explain leverage behaviour in Pakistan? Applied Financial Economics, 19(17), 1365 - 1370. http://dx.doi.org/10.1080/09603100902817592

Riahi-Belkaoui, A. (1996). Internationalization, diversification strategy and ownership structure: implications for French MNE performance. International Business Review, 5(4), 367-376. http://dx.doi.org/10.1016/0969-5931(96)00018

Robins, J. \& Wiersema, M. F. (1995). A resource based approach to the multibusiness firm: Empirical analysis of portfolio interrelationships and corporate financial performance. Strategic Management Journal, 16(4), 277-299. http://dx.doi.org/10.1002/smj.4250160403

Sheikh, N. A. \& Wang, Z. (2011). Determinants of capital structure: An empirical study of firms in manufacturing industry of Pakistan. Managerial Finance, 37(2), 117-133. http://dx.doi.org/10.1108/03074351111103668

Singh, M., Davidson, W. N. \& Suchard, J. (2003). Corporate diversification strategies and capital structure. The Quarterly Review of Economics and Finance, 43(1), 147-167. http://dx.doi.org/10.1016/S1062-9769(02)00124-

$\mathrm{Su}, \mathrm{L}$. D. Ownership structure, corporate diversification and capital structure. Management Decision, 48(2), 314-339. http://dx.doi.org/10.1108/00251741011022644

Table 1. Diversification variables, theirs proxies and relationships as found in the literature

\begin{tabular}{|l|l|l|l|}
\hline Variables & Proxy & Identified relationship & References \\
\hline $\begin{array}{l}\text { Related } \\
\text { diversification }\end{array}$ & $\begin{array}{l}\text { SIC (Standard Industrial classification codes) are } \\
\text { used. }\end{array}$ & $\begin{array}{l}\text { Negative relationship with } \\
\text { debt }\end{array}$ & $\begin{array}{l}\text { (La Rocca, et al., } \\
\text { 2009) }\end{array}$ \\
\hline $\begin{array}{l}\text { Related } \\
\text { diversification }\end{array}$ & $\begin{array}{l}\text { SSIC(Singapore Standard Industrial classification) } \\
\text { codes, product segments were classified as related } \\
\text { if they contained the same first three digits of the } \\
\text { SSIC }\end{array}$ & $\begin{array}{l}\text { Negative relationship with } \\
\text { debt }\end{array}$ & $\begin{array}{l}\text { (Lim, Das, \& Das, } \\
2009)\end{array}$ \\
\hline Diversification & $\begin{array}{l}\text { Two proxies used: } \\
\text { Herfindahl index(HERF) } \\
\text { Entropy Index (ENTROP) }\end{array}$ & $-\begin{array}{l}\text { No significant relationship } \\
\text { found between } \\
\text { diversification and debt } \\
\text { level }\end{array}$ & $\begin{array}{l}\text { (Menéndez-Alonso, } \\
2003)\end{array}$ \\
\hline $\begin{array}{l}\text { Diversification } \\
\text { of MNCs }\end{array}$ & $\begin{array}{l}\text { Degree of multinationality MUL measured by the } \\
\text { ratio of foreign taxes to total taxes. }\end{array}$ & $\begin{array}{l}\text { Positive relationship with } \\
\text { debt }\end{array}$ & $\begin{array}{l}\text { (Chkir \& Cosset, } \\
2001)\end{array}$ \\
\hline $\begin{array}{l}\text { Related } \\
\text { Diversification }\end{array}$ & Using group sales and corporate sales & $\begin{array}{l}\text { Negative relationship with } \\
\text { debt }\end{array}$ & (Su) \\
\hline $\begin{array}{l}\text { Related } \\
\text { Diversification }\end{array}$ & Entropy indices used to calculate the variable & $\begin{array}{l}\text { Negative relationship with } \\
\text { debt }\end{array}$ & $\begin{array}{l}\text { (Kochhar \& Hitt, } \\
1998)\end{array}$ \\
\hline $\begin{array}{l}\text { Unrelated } \\
\text { Diversification }\end{array}$ & SIC codes are used. & $\begin{array}{l}\text { Negative relationship with } \\
\text { debt }\end{array}$ & $\begin{array}{l}\text { (La Rocca, et al., } \\
\text { 2009) }\end{array}$ \\
\hline $\begin{array}{l}\text { Unrelated } \\
\text { Diversification }\end{array}$ & $\begin{array}{l}\text { SSIC codes, product segments were classified as } \\
\text { unrelated if they did not contain the same first three } \\
\text { digits of the SSIC }\end{array}$ & $\begin{array}{l}\text { Positive relationship with } \\
\text { debt }\end{array}$ & (Lim, et al., 2009) \\
\hline $\begin{array}{l}\text { Unrelated } \\
\text { Diversification }\end{array}$ & Using group sales and corporate sales & $\begin{array}{l}\text { Positive relationship with } \\
\text { debt }\end{array}$ & $\begin{array}{l}\text { positive relationship with } \\
\text { debt }\end{array}$ \\
\hline $\begin{array}{l}\text { Unrelated } \\
\text { Diversification }\end{array}$ & Entropy indices used to calculated the variable \\
\hline
\end{tabular}


Table 2. Variables included in the study

\begin{tabular}{|c|c|c|}
\hline \multicolumn{3}{|c|}{ INDEPENDENT VARIABLES } \\
\hline Reasoning for taking a particular proxy & Variables & Proxies \\
\hline $\begin{array}{l}\text { Lack of any system to grade the diversification level of Pakistani } \\
\text { firms we classify the firms using product diversification criterion: } \\
\text { firms producing single product as specialized and those producing } \\
\text { more than one product as diversified. }\end{array}$ & $\begin{array}{c}\text { Product } \\
\text { diversification }\end{array}$ & $\begin{array}{l}\text { Single or multiple } \\
\text { products }\end{array}$ \\
\hline $\begin{array}{l}\text { Those firms which have been exporting in the record were included } \\
\text { as geographically diversified and others selling their products } \\
\text { locally were classified as specialized }\end{array}$ & $\begin{array}{c}\text { Geographic } \\
\text { diversification }\end{array}$ & Exporting or not \\
\hline $\begin{array}{l}\text { Fatemi, A. M. (1988)., Alonso, E., 2003, D. Aoun and A. } \\
\text { Heshmati, } 2010\end{array}$ & Size of firm & Log of Total assets \\
\hline (La Rocca, et al., 2009) & Tangibility & $\begin{array}{l}\text { Fixed assets/Total } \\
\text { assets }\end{array}$ \\
\hline Alonso, E., 2003 & Growth & $\begin{array}{l}\text { Sales }_{\mathrm{t}}-\text { Sales }_{\mathrm{t}-1} / \\
\text { Sales }_{\mathrm{t}-1} \\
\end{array}$ \\
\hline (La Rocca, et al., 2009), (Harris and Raviv, 1991) & Return on assets & EBIT/Total assets \\
\hline \multicolumn{3}{|l|}{ DEPENDENT VARIABLES } \\
\hline (La Rocca, et al., 2009), (Qureshi, 2009), and many others & Debt ratio & $\begin{array}{l}\text { Total liabilities/ } \\
\text { Total liabilities }+ \\
\text { Total equity }\end{array}$ \\
\hline $\begin{array}{l}\text { (G. Qian, J. Li, 2002,) (La Rocca, et al., 2009), (Harris and Raviv, } \\
\text { 1991) }\end{array}$ & $\begin{array}{c}\text { ROA(for } \\
\text { profitability) }\end{array}$ & EBIT/Total assets \\
\hline
\end{tabular}

Table 3. Descriptive statistics

\begin{tabular}{|l|r|r|r|r|r|}
\hline & $\mathrm{N}$ & Minimum & Maximum & \multicolumn{1}{c|}{ Mean } & Std. Deviation \\
\hline Pro-diversification & 74 & .00 & 1.00 & .5135 & .50323 \\
\hline Geo-diversification & 74 & .00 & 1.00 & .3919 & .49151 \\
\hline ROA & 74 & -15.00 & 31.55 & 5.5195 & 10.71950 \\
\hline Size of firm & 74 & 1.21 & 4.37 & 2.9835 & .56205 \\
\hline Tangibility & 74 & .05 & .87 & .4858 & .20270 \\
\hline Growth & 74 & -8.49 & 108.85 & 18.0319 & 15.46606 \\
\hline Debt ratio & 74 & .08 & 9.99 & 1.4851 & 2.08284 \\
\hline Valid N (list wise) & 74 & & & & \\
\hline
\end{tabular}


Table 4. Correlation among the variables

\begin{tabular}{|l|l|c|c|l|}
\hline \multicolumn{2}{|c|}{ Two variables showing correlation } & Sig level & Value & \multicolumn{1}{|c|}{ Relationship } \\
\hline Product diversification & Return on assets & .000 & .470 & Strong positive \\
\hline Product diversification & Tangibility & .000 & -.458 & Strong negative \\
\hline Product diversification & Debt ratio & .017 & .277 & Positive \\
\hline Geo diversification & Size of firm & .010 & .299 & Positive \\
\hline Geo diversification & Growth & .046 & .232 & Positive \\
\hline Geo diversification & Debt ratio & .025 & .260 & Positive \\
\hline Return on assets & Tangibility & .000 & -.490 & Strong negative \\
\hline
\end{tabular}

Table 5. Capital structure as dependent variable

\begin{tabular}{|c|c|c|c|c|}
\hline $\mathbf{R}$ & $\mathbf{R}^{2}$ & $\begin{array}{c}\text { Regression } \\
\text { sum of square }\end{array}$ & $\begin{array}{c}\text { Residual sum } \\
\text { of squares }\end{array}$ & $\begin{array}{c}\begin{array}{c}\text { Significance } \\
\text { level }\end{array} \\
\end{array}$ \\
\hline .572 & .327 & 103.566 & 213.123 & .000 \\
\hline \multicolumn{2}{|c|}{ Regression } & & & \\
\hline $\begin{array}{c}\text { Independent } \\
\text { variable }\end{array}$ & $\begin{array}{c}\text { Dependent } \\
\text { variable }\end{array}$ & Sig. level & beta & Relationship \\
\hline $\begin{array}{c}\text { Product } \\
\text { diversification }\end{array}$ & Debt ratio & .000 & .521 & Positive \\
\hline $\begin{array}{c}\text { Geographic } \\
\text { diversification }\end{array}$ & Debt ratio & .015 & .272 & Positive \\
\hline Profitability & Debt ratio & .012 & -.329 & Negative \\
\hline Tangibility & Debt ratio & .039 & .263 & Positive \\
\hline
\end{tabular}

Table 6. Profitability as dependent variable

\begin{tabular}{|c|c|c|c|c|}
\hline $\mathbf{R}$ & $\mathbf{R}^{2}$ & $\begin{array}{c}\text { Regression } \\
\text { sum of } \\
\text { squares }\end{array}$ & $\begin{array}{l}\text { Residual } \\
\text { sum of } \\
\text { squares }\end{array}$ & $\begin{array}{c}\text { Significance } \\
\text { level }\end{array}$ \\
\hline .659 & .434 & 3643.132 & 4745.136 & .000 \\
\hline \multicolumn{2}{|c|}{ Regression } & \multirow{2}{*}{ Sig level } & \multirow{2}{*}{ Beta } & \multirow[b]{2}{*}{ Relationship } \\
\hline $\begin{array}{c}\text { Independent } \\
\text { variable } \\
\end{array}$ & $\begin{array}{c}\text { Dependent } \\
\text { variable } \\
\end{array}$ & & & \\
\hline $\begin{array}{c}\text { Product } \\
\text { diversification }\end{array}$ & Return on assets & .001 & .402 & Positive \\
\hline Size of firm & Return on assets & .023 & .228 & Positive \\
\hline Tangibility & Return on assets & .016 & -.279 & Negative \\
\hline Debt ratio & Return on assets & .012 & -.277 & Negative \\
\hline
\end{tabular}


Table 7. Chemical sector - Capital structure as dependent variable

\begin{tabular}{|c|c|c|c|c|}
\hline $\mathbf{R}$ & $\mathbf{R}^{2}$ & $\begin{array}{c}\text { Regression sum } \\
\text { of squares }\end{array}$ & $\begin{array}{c}\text { Residual sum } \\
\text { of squares }\end{array}$ & $\begin{array}{c}\text { Significance } \\
\text { level }\end{array}$ \\
\hline .732 & .536 & 132.409 & 114.791 & .008 \\
\hline \multicolumn{2}{|c|}{$\begin{array}{c}\text { Regression } \\
\end{array}$} & \multirow[b]{2}{*}{ Sig level } & \multirow[b]{2}{*}{ Beta } & \multirow[b]{2}{*}{ Relationship } \\
\hline $\begin{array}{l}\text { Independent } \\
\text { variable }\end{array}$ & $\begin{array}{c}\text { Dependent } \\
\text { variable }\end{array}$ & & & \\
\hline $\begin{array}{c}\text { Geographic } \\
\text { diversification }\end{array}$ & Debt ratio & .008 & .463 & Positive \\
\hline Profitability & Debt ratio & .044 & -.408 & Negative \\
\hline Tangibility & Debt ratio & .071 & .330 & Positive \\
\hline
\end{tabular}

Table 8. Chemical sector - Profitability as dependent variable

\begin{tabular}{|c|c|c|c|c|}
\hline $\mathbf{R}$ & $\mathbf{R}^{2}$ & $\begin{array}{c}\text { Regression } \\
\text { sum of } \\
\text { squares } \\
\end{array}$ & $\begin{array}{c}\text { Residual } \\
\text { sum of } \\
\text { squares } \\
\end{array}$ & $\begin{array}{c}\text { Significance } \\
\text { level }\end{array}$ \\
\hline .771 & .594 & 1261.746 & 863.584 & .000 \\
\hline \multicolumn{2}{|c|}{ Regression } & & \multirow[b]{2}{*}{ Beta } & \\
\hline $\begin{array}{c}\text { Independent } \\
\text { variable }\end{array}$ & $\begin{array}{c}\text { Dependent } \\
\text { variable }\end{array}$ & Sig level & & Relationship \\
\hline $\begin{array}{c}\text { Product } \\
\text { diversification }\end{array}$ & Return on assets & .051 & .293 & Positive \\
\hline Tangibility & Return on assets & .039 & -.289 & Negative \\
\hline Growth & Return on assets & .013 & .343 & Positive \\
\hline
\end{tabular}

Table 9. Food sector - Capital structure as dependent variable

\begin{tabular}{|c|c|c|c|c|}
\hline $\mathbf{R}$ & $\mathbf{R}^{2}$ & $\begin{array}{c}\text { Regression } \\
\text { sum of squares }\end{array}$ & $\begin{array}{c}\text { Residual sum } \\
\text { of squares }\end{array}$ & $\begin{array}{c}\text { Significance } \\
\text { level }\end{array}$ \\
\hline .737 & .543 & 8.928 & 7.502 & .000 \\
\hline \multicolumn{2}{|c|}{ Regression } & \multirow[b]{2}{*}{ Sig level } & \multirow[b]{2}{*}{ Beta } & \multirow[b]{2}{*}{ Relationship } \\
\hline $\begin{array}{c}\text { Independent } \\
\text { variable }\end{array}$ & $\begin{array}{c}\text { Dependent } \\
\text { variable }\end{array}$ & & & \\
\hline Size of firm & Debt ratio & .046 & -.308 & Negative \\
\hline Profitability & Debt ratio & .002 & -.540 & Negative \\
\hline Tangibility & Debt ratio & .017 & .362 & Positive \\
\hline
\end{tabular}

Table 10. Food sector - Profitability as dependent variable

\begin{tabular}{|c|c|c|c|c|}
\hline R & $\mathbf{R}^{\mathbf{2}}$ & $\begin{array}{c}\text { Regression sum } \\
\text { of squares }\end{array}$ & $\begin{array}{c}\text { Residual sum } \\
\text { of squares }\end{array}$ & $\begin{array}{c}\text { Significance } \\
\text { level }\end{array}$ \\
\hline \multicolumn{2}{|c|}{ Regression } & 2317.371 & 1330.774 & .000 \\
\hline $\begin{array}{c}\text { Independent } \\
\text { variable }\end{array}$ & $\begin{array}{c}\text { Dependent } \\
\text { variable }\end{array}$ & Sig level & Beta & Relationship \\
\hline $\begin{array}{c}\text { Product } \\
\text { diversification }\end{array}$ & Return on assets & .002 & .396 & Positive \\
\hline Debt ratio & Return on assets & .002 & -.432 & Negative \\
\hline
\end{tabular}


Table 11. Capital structure of large firms

\begin{tabular}{|c|c|c|c|c|}
\hline 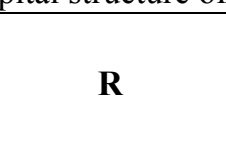 & $\mathbf{R}^{2}$ & $\begin{array}{l}\text { Regression } \\
\text { sum of } \\
\text { squares }\end{array}$ & $\begin{array}{l}\text { Residual } \\
\text { sum of } \\
\text { squares }\end{array}$ & Significance level \\
\hline .618 & .306 & 121.125 & 195.565 & .000 \\
\hline \multicolumn{2}{|c|}{ Regression } & & & \\
\hline $\begin{array}{l}\text { Independent } \\
\text { variable }\end{array}$ & $\begin{array}{l}\text { Dependent } \\
\text { variable }\end{array}$ & Sig. level & beta & Relationship \\
\hline $\begin{array}{c}\text { Geographic } \\
\text { diversification }\end{array}$ & Debt ratio & .014 & .272 & Positive \\
\hline Profitability & Debt ratio & .059 & -.254 & Negative \\
\hline Tangibility & Debt ratio & .024 & .281 & Positive \\
\hline
\end{tabular}

Table 12. Capital structure of medium firms

\begin{tabular}{|c|c|c|c|c|}
\hline $\mathbf{R}$ & $\mathbf{R}^{2}$ & $\begin{array}{c}\text { Regression } \\
\text { sum of } \\
\text { squares }\end{array}$ & $\begin{array}{c}\text { Residual } \\
\text { sum of } \\
\text { squares }\end{array}$ & Significance level \\
\hline .764 & .446 & 26.980 & 19.207 & .008 \\
\hline \multicolumn{2}{|c|}{ Regression } & \multirow{2}{*}{ Sig. level } & beta & Relationship \\
\cline { 1 - 2 } $\begin{array}{c}\text { Independent } \\
\text { variable }\end{array}$ & $\begin{array}{c}\text { Dependent } \\
\text { variable }\end{array}$ & & & Negative \\
\hline Growth & Debt ratio & .021 & -.487 & Negative \\
\hline Profitability & Debt ratio & .029 & -.476 & \\
\hline
\end{tabular}

Table 13. Capital structure of small firms

\begin{tabular}{|c|c|c|c|c|}
\hline $\mathbf{R}$ & $\mathbf{R}^{2}$ & $\begin{array}{c}\text { Regression } \\
\text { sum of } \\
\text { squares }\end{array}$ & $\begin{array}{c}\text { Residual } \\
\text { sum of } \\
\text { squares }\end{array}$ & Significance level \\
\hline .821 & .558 & 79.127 & 38.352 & .002 \\
\hline \multicolumn{2}{|c|}{$\begin{array}{l}\text { Regression } \\
\end{array}$} & \multirow[b]{2}{*}{ Sig. level } & \multirow[b]{2}{*}{ beta } & \multirow[b]{2}{*}{ Relationship } \\
\hline $\begin{array}{c}\text { Independent } \\
\text { variable }\end{array}$ & $\begin{array}{c}\text { Dependent } \\
\text { variable }\end{array}$ & & & \\
\hline $\begin{array}{c}\text { Geographic } \\
\text { diversification }\end{array}$ & Debt ratio & .000 & .732 & Positive \\
\hline
\end{tabular}

Table 14. Profitability of large firms

\begin{tabular}{|c|c|c|c|c|}
\hline $\mathbf{R}$ & $\mathbf{R}^{2}$ & $\begin{array}{c}\text { Regression } \\
\text { sum of } \\
\text { squares } \\
\end{array}$ & $\begin{array}{c}\text { Residual } \\
\text { sum of } \\
\text { squares }\end{array}$ & $\begin{array}{c}\text { Significance } \\
\text { level }\end{array}$ \\
\hline .767 & .451 & 2051.953 & 1436.648 & .007 \\
\hline \multicolumn{2}{|c|}{ Regression } & \multirow[b]{2}{*}{ Sig. level } & \multirow[b]{2}{*}{ beta } & \multirow[b]{2}{*}{ Relationship } \\
\hline $\begin{array}{l}\text { Independent } \\
\text { variable }\end{array}$ & $\begin{array}{l}\text { Dependent } \\
\text { variable }\end{array}$ & & & \\
\hline $\begin{array}{l}\text { Product } \\
\text { diversification }\end{array}$ & ROA & .013 & .827 & Positive \\
\hline Tangibility & $\mathrm{ROA}$ & .034 & -.493 & Negative \\
\hline
\end{tabular}


Table 15. Profitability of medium firms

\begin{tabular}{|c|c|c|c|c|}
\hline $\mathbf{R}$ & $\mathbf{R}^{2}$ & $\begin{array}{c}\text { Regression } \\
\text { sum of } \\
\text { squares } \\
\end{array}$ & $\begin{array}{c}\text { Residual } \\
\text { sum of } \\
\text { squares }\end{array}$ & Significance level \\
\hline .750 & .563 & 800.378 & 621.791 & .012 \\
\hline \multicolumn{2}{|c|}{ Regression } & \multirow[b]{2}{*}{ Sig. level } & \multirow[b]{2}{*}{ beta } & \\
\hline Independent variable & $\begin{array}{c}\text { Dependent } \\
\text { variable }\end{array}$ & & & Relationship \\
\hline Debt ratio & ROA & .029 & -.501 & Negative \\
\hline
\end{tabular}

Table 16. Profitability of small firms

\begin{tabular}{|c|c|c|c|c|}
\hline R & $\mathbf{R}^{2}$ & $\begin{array}{c}\text { Regression } \\
\text { sum of } \\
\text { squares }\end{array}$ & $\begin{array}{c}\text { Residual } \\
\text { sum of } \\
\text { squares }\end{array}$ & Significance level \\
\hline .740 & .547 & 1626.517 & 1347.097 & .021 \\
\hline \multicolumn{2}{|r|}{ Regression } & \multirow{2}{*}{ Sig. level } & beta & Relationship \\
\cline { 1 - 2 } Independent variable & $\begin{array}{c}\text { Dependent } \\
\text { variable }\end{array}$ & .070 & .449 & Positive \\
\hline Product diversification & ROA & &
\end{tabular}

